\title{
Corrosion Behavior of Carbon Steel in Synthetically Produced Oil Field Seawater
}

\author{
Subir Paul, Anjan Pattanayak, and Sujit K. Guchhait \\ Department of Metallurgical and Material Engineering, Jadavpur University, Kolkata 700032, India \\ Correspondence should be addressed to Subir Paul; spmet4@gmail.com
}

Received 16 September 2014; Accepted 14 November 2014; Published 17 December 2014

Academic Editor: Chi Tat Kwok

Copyright (C) 2014 Subir Paul et al. This is an open access article distributed under the Creative Commons Attribution License, which permits unrestricted use, distribution, and reproduction in any medium, provided the original work is properly cited.

\begin{abstract}
The life of offshore steel structure in the oil production units is decided by the huge corrosive degradation due to $\mathrm{SO}_{4}{ }^{2-}, \mathrm{S}^{2-}$, and $\mathrm{Cl}^{-}$, which normally present in the oil field seawater. Variation in $\mathrm{pH}$ and temperature further adds to the rate of degradation on steel. Corrosion behavior of mild steel is investigated through polarization, EIS, XRD, and optical and SEM microscopy. The effect of all 3 species is huge material degradation with $\mathrm{FeS}_{x}$ and $\mathrm{FeCl}_{3}$ and their complex as corrosion products. EIS data match the model of Randle circuit with Warburg resistance. Addition of more corrosion species decreases impedance and increases capacitance values of the Randle circuit at the interface. The attack is found to be at the grain boundary as well as grain body with very prominent sulphide corrosion crack.
\end{abstract}

\section{Introduction}

The severe corrosion of the submersed structures in the oil field at the production site and crude oil transportation is unpredictable and is a major component of the total corrosion loss in oil and gas industries. The corrosion species in the aqueous oil field seawater are $\mathrm{CO}_{3}{ }^{2-}, \mathrm{S}^{2-}, \mathrm{Cl}^{-}, \mathrm{SO}_{4}{ }^{2-}$, and $\mathrm{O}$ (Table 1) [1] which are also influenced by the variation of $\mathrm{pH}$ and temperature. $\mathrm{CO}_{3}{ }^{2-}$ and $\mathrm{S}^{2-}$ are formed from $\mathrm{CO}_{2}$ and $\mathrm{H}_{2} \mathrm{~S}$ of the oil in the aqueous environment. And $\mathrm{Cl}^{-}, \mathrm{SO}_{4}{ }^{2-}$, and $\mathrm{O}$ are present in the seawater. Besides these parameters, there are fluid dynamics of sea water and suspended solids and sands, influencing the erosion corrosion of the marine structures. Crude oil and natural gas can carry various highimpurity products which are inherently corrosive. In the case of oil and gas wells and pipelines, such highly corrosive media are carbon dioxide $\left(\mathrm{CO}_{2}\right)$, hydrogen sulfide $\left(\mathrm{H}_{2} \mathrm{~S}\right)$, and free water [2].

The effect of any individual parameter on corrosion rate has been studied extensively [3-6]. But the conjoint effect of the above mentioned parameters and interfering effects and interactions are complex and are not very well understood. The salts and sulfide compounds dissolved in crude oil can provoke the formation of a corrosive aqueous solution whose chemical composition involves the presence of both hydrochloric acid (HCI) and hydrogen sulfide $\left(\mathrm{H}_{2} \mathrm{~S}\right)$ $[3,4]$. Corrosion mitigation in the oil field industry has traditionally been performed by combining methods for measuring the corrosion rates such as corrosion coupons and regular pipeline inspections with prevention strategies [6]. But that required years to get empirical results and could not be applied to other geographical locations of different sea water chemistry. All the factors make the corrosion mechanisms in the oil fields very complex with high degree of interaction among the species. Several previous studies have been performed related to the corrosion process of iron and steel in $\mathrm{H}_{2} \mathrm{~S}$ solutions [4, 7-13]. These works studied the influence of $\mathrm{H}_{2} \mathrm{~S}$ on the corrosion phenomena at ambient temperature. In $\mathrm{H}_{2} \mathrm{~S}$-containing solutions, the corrosion process of metal may be accompanied by the formation of a sulfide film on the metal surface and leads to more complicated corrosion behavior. Previous researches [14-16] have shown that $\mathrm{H}_{2} \mathrm{~S}$ had a remarkable acceleration effect on both the anodic iron dissolution and the cathodic evolution in most cases but $\mathrm{H}_{2} \mathrm{~S}$ may exhibit an inhibitive effect on the corrosion of iron or steel weld. Recently, the influence of $\mathrm{H}_{2} \mathrm{~S}$ concentration on the corrosion behavior of carbon steel at $90^{\circ} \mathrm{C}$ has been investigated [15]. Physical modeling of ships and offshore structures in ocean water by Melchers et al. [17-19] and Shehadeh and Hassan [20] adds to 
TABLE 1: Ions present in typical oil field seawater.

\begin{tabular}{|c|c|c|c|c|}
\hline \multicolumn{2}{|c|}{ Species typically found in oil field brines } & \multicolumn{2}{|c|}{ Element } & \multirow{2}{*}{$\begin{array}{c}\text { Concentration } \mathrm{mg} / \mathrm{L} \\
31\end{array}$} \\
\hline $\mathrm{CO}_{2}$ & Dissolved carbon dioxide & Barium & $\mathrm{Ba}^{2+}$ & \\
\hline $\mathrm{H}_{2} \mathrm{CO}_{3}$ & Carbonic acid & Boron & B & 6 \\
\hline $\mathrm{HCO}_{3}^{-}$ & Bicarbonate ion & Calcium & $\mathrm{Ca}^{2+}$ & 284 \\
\hline $\mathrm{CO}_{3}{ }^{2-}$ & Carbonate ion & Iron & $\mathrm{Fe}^{3+}$ & 55.85 \\
\hline $\mathrm{H}^{+}$ & Hydrogen ion & Magnesium & $\mathrm{Mg}^{2+}$ & 24.31 \\
\hline $\mathrm{OH}^{-}$ & Hydroxide ion & Phosphorous & $\mathrm{P}^{3-}$ & 1 \\
\hline $\mathrm{Fe}^{2+}$ & Iron ion & Potassium & $\mathrm{K}$ & 50 \\
\hline $\mathrm{Cl}^{-}$ & Chloride ion & Sodium & $\mathrm{Na}$ & 4770 \\
\hline $\mathrm{Na}^{+}$ & Sodium ion & Strontium & $\mathrm{Sr}^{2+}$ & 83 \\
\hline $\mathrm{K}^{+}$ & Potassium & Chloride & $\mathrm{Cl}^{-}$ & 7480 \\
\hline $\mathrm{Ca}^{2+}$ & Calcium ion & Bromide & $\mathrm{Br}^{-}$ & 20 \\
\hline $\mathrm{Mg}^{2+}$ & Magnesium ion & Sulphate & $\mathrm{SO}_{4}{ }^{2-}$ & 21 \\
\hline $\mathrm{Ba}^{2+}$ & Barium ion & Nitrate & $\mathrm{NO}_{3}{ }^{-}$ & 0.50 \\
\hline $\mathrm{Sr}^{2+}$ & Strontium ion & Hydroxyl & $\mathrm{OH}^{-}$ & 0 \\
\hline $\mathrm{CH}_{3} \mathrm{COOH}(\mathrm{HAc})$ & Acetic acid & Carbonate & $\mathrm{CO}_{3}{ }^{2-}$ & 0 \\
\hline $\mathrm{CH}_{3} \mathrm{COO}^{-}\left(\mathrm{Ac}^{-}\right)$ & Acetate ion & Bicarbonate & $\mathrm{HCO}_{3}^{-}$ & 500 \\
\hline $\mathrm{HSO}_{4}{ }^{-}$ & Bisulphate ion & Dissolved $\mathrm{CO}_{2}$ & $\mathrm{CO}_{2}$ & 92.4 \\
\hline \multirow[t]{4}{*}{$\mathrm{SO}_{4}^{2-}$} & Sulphate ion & Specific gravity & & 1.014 \\
\hline & & $\mathrm{pH}$ & & 6.58 \\
\hline & & Resistivity & & $0.4405 \mathrm{Ohm}$ \\
\hline & & Total dissolved solids 1 & & $3.453 \mathrm{mg}$ \\
\hline
\end{tabular}

better understanding of the present investigation. However, little research has been done on the corrosion behavior of carbon steel in the presence of both $\mathrm{H}_{2} \mathrm{~S}$ and $\mathrm{NaCl}$ at ambient and elevated temperature.

Corrosion mechanisms in oil field systems are complex and are showing high degrees of interaction between corrosion species, products, and oil field metallurgies. The interactions of sulfate and chloride are of interest in this work, since presence of sulfate ions, in oilfield produced water, strongly influence corrosion mechanisms. While there are many research works on the effects of $\mathrm{CO}_{2}$ and $\mathrm{H}_{2} \mathrm{~S}$ on corrosion of carbon steel, those of conjoint effects of $\mathrm{S}^{2-}$, $\mathrm{Cl}^{-}$, and $\mathrm{SO}_{4}{ }^{2-}$ are much less. The present investigation aims to study the conjoint effects of $\mathrm{S}^{2-}, \mathrm{Cl}^{-}$, and $\mathrm{SO}_{4}{ }^{2-}$ along with variation of $\mathrm{pH}$ and temperature on carbon steel. The corrosive species included are sulfate, chloride, hydrogen sulfide, temperature, and $\mathrm{pH}$. Sulphate and chloride were added as $\mathrm{Na}_{2} \mathrm{SO}_{4}$ and $\mathrm{NaCl}$. Hydrogen sulfide was introduced to the corrosion cell with the following reaction:

$$
\mathrm{Na}_{2} \mathrm{~S}+\mathrm{H}_{2} \mathrm{SO}_{4}=\mathrm{H}_{2} \mathrm{~S}+\mathrm{FeSO}_{4}
$$

The effect on corrosion of these species was examined through polarization experimentation using a threeelectrode glass corrosion cell and potentiostat. Electrochemical AC impedance spectroscopy studies were also carried out for better understanding of electrochemical effects of corrosive species on electrical phenomenon occurring at metalsolution interface. The corroded and uncorroded substrates were characterized by XRD. The morphology of the corroded surface was investigated by optical microscopy and SEM.

\section{Experimental Methods}

2.1. Polarization Studies. Electrochemical measurements were conducted using Gamry Potentiostat instrument coupled with Echem analyst software, controlled by a personal computer, in a conventional three-electrode cell systems. The working electrode was carbon steel, the counter electrode was graphite, and a saturated calomel electrode (SCE) acted as the reference electrode. Experiments were performed in different concentrations of $\mathrm{Cl}^{-}, \mathrm{SO}_{4}{ }^{2-}$, and $\mathrm{S}^{2-}$ solutions, at preselected $\mathrm{pH}$ and temperature, to determine the corrosion potential $E_{\text {corr }}$ and corrosion current $i_{\text {corr }}$. The potential was scanned between $-1.5 \mathrm{~V}$ and $1 \mathrm{~V}$ at a scan rate of $1 \mathrm{mV} / \mathrm{s}$.

2.2. Electrochemical Impedance Spectroscopy (EIS). The experimental arrangement was the same as that of polarization studies. The electrochemical cell was connected to an impedance analyzer (EIS300 controlled by Echem analyst software) for electrochemical impedance spectroscopy. The electrochemical impedance spectra were obtained at frequencies between $300 \mathrm{kHz}$ and $0.01 \mathrm{~Hz}$. The amplitude of the sinusoidal wave was $10 \mathrm{mV}$. The following results and information are obtained from the EIS experiments: Polarization resistance $\left(R_{p}\right)$, electrolyte resistance $\left(R_{u}\right)$, double layer capacitance $\left(C_{\mathrm{dl}}\right)$, capacitive load or constant phase element, $\mathrm{CPE}(Y)$, and $\alpha$ which is defined from the capacitive impedance equation $Z=1 / C(j w)^{-\alpha}$.

Capacitors in EIS experiments often do not behave ideally. Instead, they act like a constant phase element (CPE). The exponent $\alpha=1$ for pure capacitance. For a constant 
phase element, the exponent $\alpha$ is less than one. The "double layer capacitor" on real cells often behaves like a CPE instead of like a pure capacitor.

2.3. X-Ray Diffraction (XRD) Analysis. The X-ray diffraction technique is used to define the crystalline structure and the crystalline phases. This test was done using a Rigaku Ultima III X-Ray Diffractometer for recording the diffraction traces of the samples with monochromatized $\mathrm{Cu} \mathrm{K}_{\alpha}$ radiation, at room temperature; the scan region $(2 \theta)$ ranged from $10^{\circ}$ to $100^{\circ}$ at a scan rate of $5^{\circ} \mathrm{min}^{-1}$.

2.4. Scanning Electron Microscope (SEM) Morphology. The electron micrographs were studied by SEM with accelerating voltage $30 \mathrm{kV}$, magnification up to $300,000 \mathrm{x}$, and resolution of $3.5 \mathrm{~nm}$. The images of the corroded samples were photographed at low and high magnification.

\section{Results and Discussions}

The effects of $\mathrm{Cl}^{-}, \mathrm{SO}_{4}{ }^{2-}, \mathrm{S}^{2-}, \mathrm{pH}$, and temperature on degradation behavior of carbon steel were studied by potentiostatic polarization to determine corrosion current and corrosion potential. The various electrical properties at the metal-solution interface were determined by electrochemical impedance spectroscopy (EIS). The presence of different elements on corroded surface was detected by XRD. The morphology of the degraded surfaces was characterized by optical microscopy and SEM. Before going into the experimental findings of the effects of different interfering ions, it is worthwhile to discuss the basic electrochemical reactions of aqueous corrosion of steel in the presence of those ions.

The main electrochemical anodic and cathodic reactions for the corrosion of carbon steel in aqueous oil fields environments in presences of the ions are as follows.

Half Cell Reactions (E versus SCE). Consider

$$
\begin{gathered}
\mathrm{Fe}=\mathrm{Fe}^{2+}+2 \mathrm{e} \quad\left(E^{0}=-.681\right) \\
\mathrm{O}_{2}+2 \mathrm{H}_{2} \mathrm{O}+4 \mathrm{e}^{-} \longrightarrow 4 \mathrm{OH}^{-} \quad\left(E^{0}=0.579\right) \\
\mathrm{H}+\mathrm{e}=\frac{1}{2} \mathrm{H}_{2} \quad\left(E^{0}=-0.241\right)
\end{gathered}
$$

In presence of $\mathrm{SO}_{4}{ }^{2-}$, present reactions are

$$
\begin{gathered}
\mathrm{SO}_{4}{ }^{2-}+2 \mathrm{e}+\mathrm{H}_{2} \mathrm{O}=2 \mathrm{SO}_{3}{ }^{2-}+\mathrm{OH} \quad\left(E^{0}=-1.177\right) \\
2 \mathrm{SO}_{3}{ }^{2-}+4 \mathrm{e}+3 \mathrm{H}_{2} \mathrm{O}=3 \mathrm{~S}_{2} \mathrm{O}_{3}{ }^{2-}+6 \mathrm{OH}^{-} \quad\left(E^{0}=-0.99\right) \\
2 \mathrm{SO}_{3}{ }^{2-}+4 \mathrm{e}+3 \mathrm{H}_{2} \mathrm{O}=\mathrm{S}+6 \mathrm{OH}^{-} \\
\mathrm{S}+2 \mathrm{e}^{-}=\mathrm{S}^{2-} \quad\left(E^{0}=-0.688\right)
\end{gathered}
$$

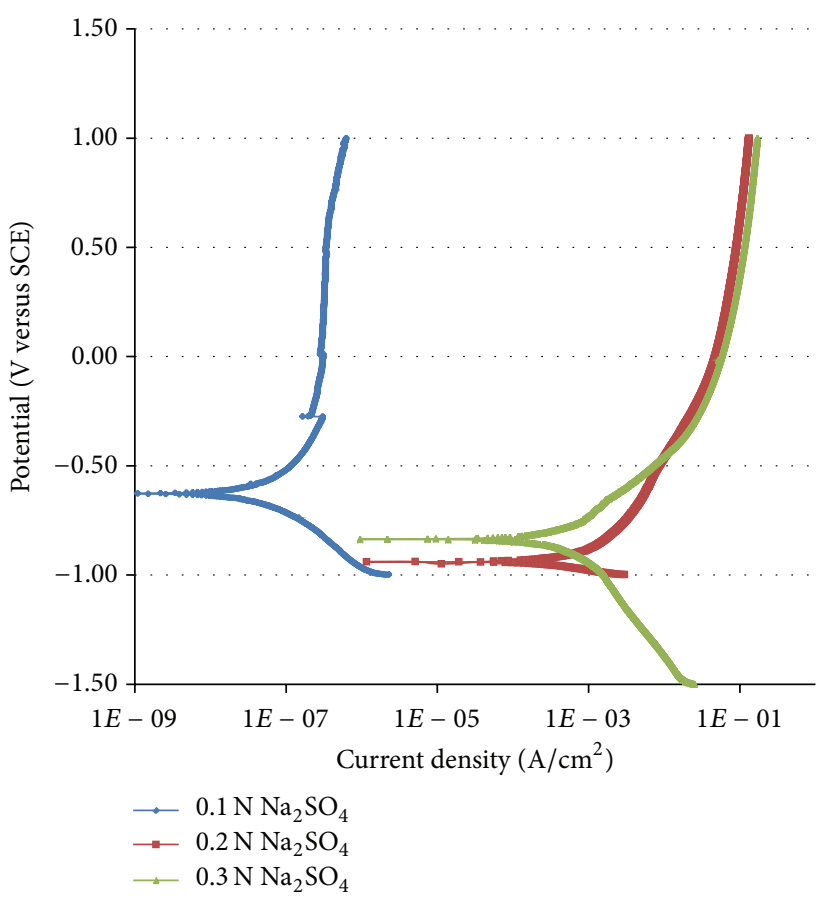

FIgURE 1: Potentiodynamic polarization curves of low carbon steel in different concentration of $\mathrm{Na}_{2} \mathrm{SO}_{4}$ solution at $\mathrm{pH} 6$ and temperature $25^{\circ} \mathrm{C}$.

In presence of $\mathrm{Na}_{2} \mathrm{~S}$ or $\mathrm{H}_{2} \mathrm{~S}\left(\mathrm{Na}_{2} \mathrm{~S}\right.$ was added in state of $\mathrm{H}_{2} \mathrm{~S}$ to understand the effect of $\mathrm{s}^{2-}$ ),

$$
\begin{gathered}
\mathrm{H}_{2} \mathrm{~S}=\mathrm{H}^{+}+\mathrm{HS}^{-} \\
\mathrm{HS}^{-}=\mathrm{H}^{+}+\mathrm{S}^{-} \quad\left(E^{0}=-0.688\right)
\end{gathered}
$$

In the presence of $\mathrm{Cl}^{-}$, that is $(\mathrm{NaCl} / \mathrm{HCl})$,

$$
\begin{gathered}
\mathrm{Fe}^{2+}+2 \mathrm{Cl}^{-}=\mathrm{FeCl}_{2} \\
\mathrm{FeCl}_{2}+2 \mathrm{H}_{2} \mathrm{O}=\mathrm{Fe}(\mathrm{OH})_{2}+2 \mathrm{H}^{+}+2 \mathrm{Cl}^{-} \\
\mathrm{FeCl}_{2}+\mathrm{Cl}^{-}=\mathrm{FeCl}_{3}+\mathrm{e} \\
\mathrm{Fe}+2 \mathrm{H}^{+}=\mathrm{Fe}^{2+}
\end{gathered}
$$

The above equations would help in better understanding of the effects of the corrosion species found in the experimental results.

\subsection{Polarization Studies}

3.1.1. Effect of $\mathrm{SO}_{4}{ }^{2-}$. Figure 1 shows the potential dynamic polarization curve with increasing $\mathrm{SO}_{4}{ }^{2-}$ concentration at $\mathrm{pH}$ 6. The $\mathrm{pH}$ of sea water normally varies from 7.5 to 8.2 . but in the oil fields due to the presence of few acidic substances, namely, carbonic acid, $\mathrm{H}_{2} \mathrm{~S}$, and other organic acids, $\mathrm{pH}$ may shift from near neutral towards the acidic side between 6 and 4 . It is seen here that the corrosion rate increases with increase in concentration of $\mathrm{SO}_{4}{ }^{2-}$. It is seen from (5)-(8) that 


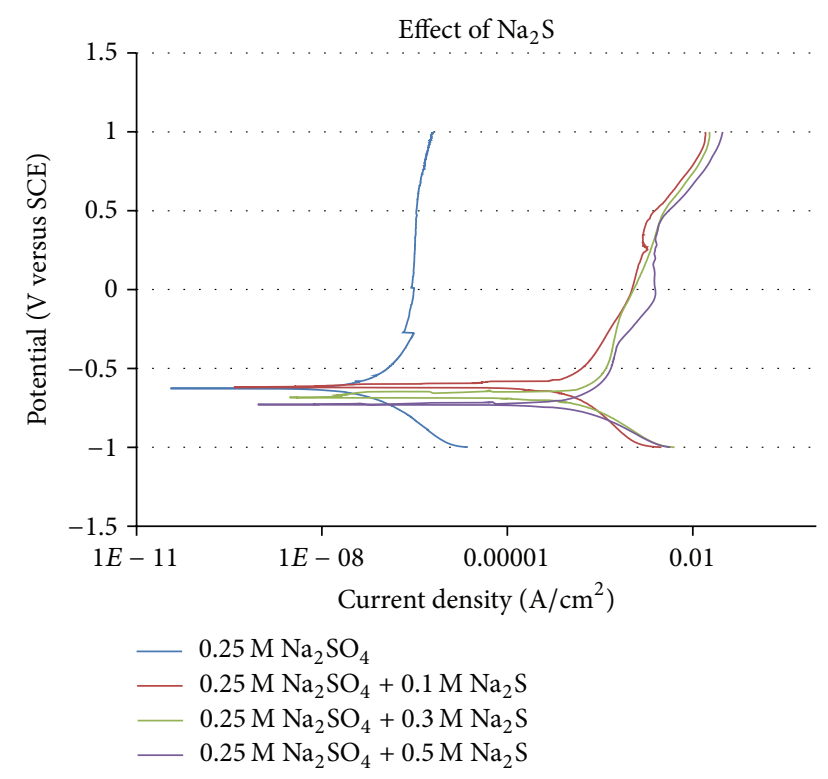

FIgURE 2: Effect of $\mathrm{S}^{2-}$ on potentiodynamic polarization curves of carbon steel in $0.25 \mathrm{M} \mathrm{Na}_{2} \mathrm{SO}_{4}$ solution at $\mathrm{pH} 6$ and temperature $25^{\circ} \mathrm{C}$.

the cathodic reduction of $\mathrm{SO}_{4}{ }^{2-}$ ions produces thiosulfate and sulphide ions, both of which are aggressive corrosion species and hence degrade the steel surface in sea water in the acidic $\mathrm{pH}$ range below the neutral medium. The corrosion product in this case should be iron sulphide or thiosulfate.

3.1.2. Effect of $\mathrm{SO}_{4}{ }^{2-}+\mathrm{S}^{2-}$. Addition of $\mathrm{S}^{2-}$ to the solution containing $\mathrm{SO}_{4}{ }^{2-}$ further enhances the corrosion rate as can be seen from Figure 2. And the $\mathrm{pH}$ has a strong effect on it. It can be seen from (11) and (12) above that the conjoint effect of $\mathrm{SO}_{4}{ }^{2-}$ and $\mathrm{S}^{-}$is the production of increasing amount of $\mathrm{S}^{-}$, as well as corrosive sulphur compound.

3.1.3. Effect of $\mathrm{SO}_{4}{ }^{2-}+\mathrm{Cl}^{-}$. Corrosion rate also increases with addition of $\mathrm{Cl}^{-}$to the solution containing $\mathrm{SO}_{4}{ }^{2-}$ (Figure 3). The rate increases with increase in $\mathrm{Cl}^{-}$concentration. It is seen from (11)-(14) above that the $\mathrm{Cl}^{-}$ions attack $\mathrm{Fe} / \mathrm{Fe}^{2+}$ with the formation of corrosion products $\mathrm{FeCl}_{2}$ and $\mathrm{FeCl}_{3} \cdot \mathrm{FeCl}_{2}$ is unstable and may hydrolyse or further react with $\mathrm{Cl}^{-}$ions to form $\mathrm{Fe}(\mathrm{OH})_{2}$ or $\mathrm{FeCl}_{3}$, respectively.

3.1.4. Effect of $\mathrm{SO}_{4}{ }^{2-}+\mathrm{S}^{2-}+\mathrm{Cl}^{-}$. The conjugate of all 3 ions which are normally present in the oil field sea water is the degradation of carbon steel structure at the highest level. It is seen from Figure 4 that $i_{\text {corr }}$ values have shifted to the right and $E_{\text {corr }}$ towards the active potential with increasing the concentration of both $\mathrm{S}^{2-}$ and $\mathrm{Cl}^{-}$.

3.1.5. Effect of $p H$. There is not any much significant effect of polarization curves with change in $\mathrm{pH}$ except at $\mathrm{pH} 11$ under alkaline condition (Figure 5), when the corrosion rate is very low. The steel is in the passive region at this $\mathrm{pH}$. The $\mathrm{pH}$ of

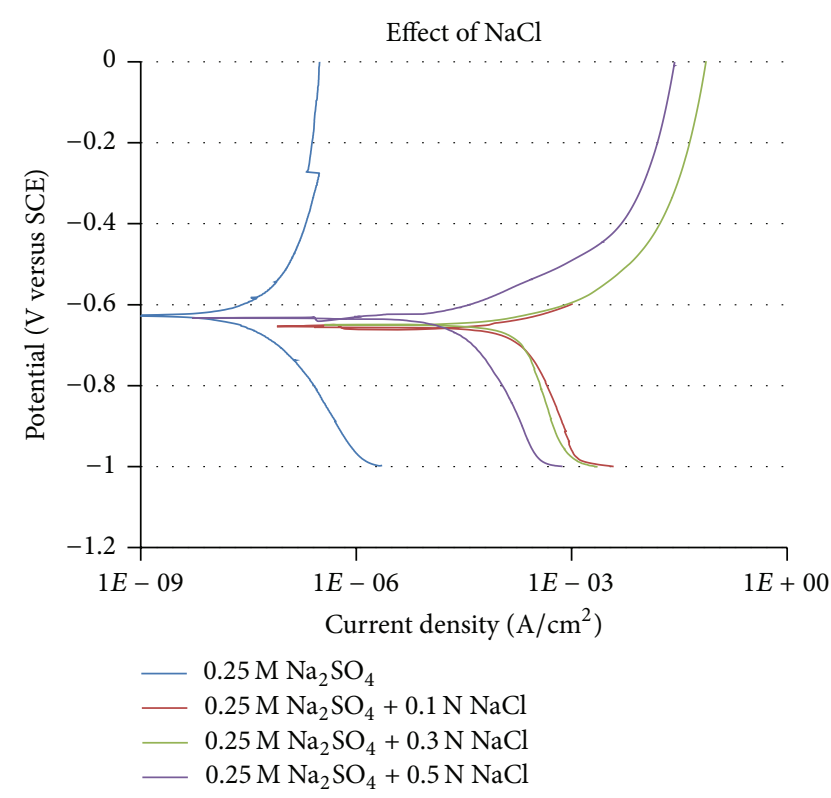

FIGURE 3: Effect of $\mathrm{Cl}^{-}$on potentiodynamic polarization curves of carbon steel in $0.25 \mathrm{M} \mathrm{Na}_{2} \mathrm{SO}_{4}$ solution at $\mathrm{pH} 8$ and temperature $25^{\circ} \mathrm{C}$.

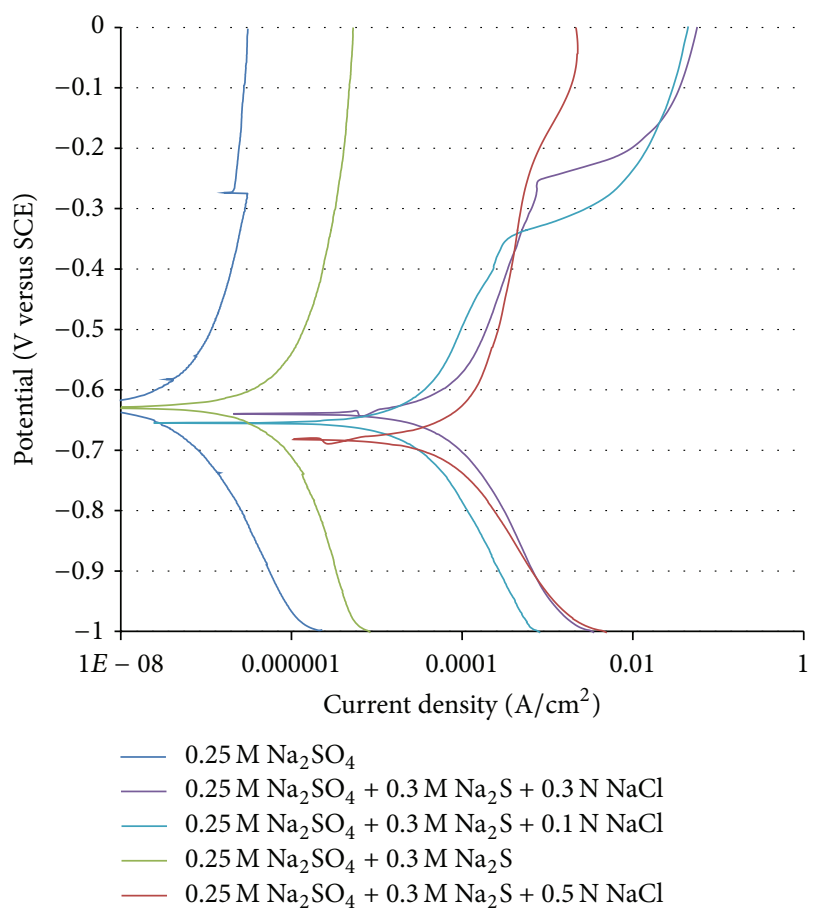

FIgURE 4: Effect of $\mathrm{Cl}^{-}+\mathrm{S}^{2-}$ on potentiodynamic polarization curves of carbon steel in $0.25 \mathrm{M} \mathrm{Na}_{2} \mathrm{SO}_{4}$ solution at $\mathrm{pH} 8$ and temperature $25^{\circ} \mathrm{C}$.

the oil field water is in the range of 4-6 when the corrosion rate is high.

3.1.6. Effect of Temperature. Temperature aggravates the material degradation (Figure 6) by increasing diffusion and mass transfer coefficient of the aggressive ions corroding 


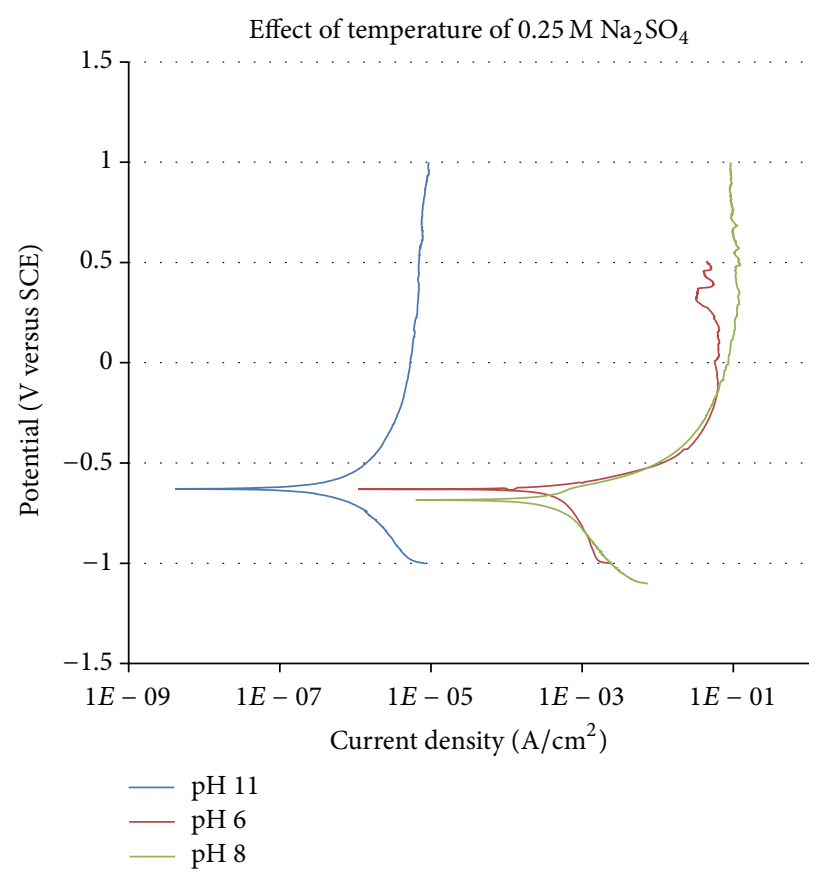

FIGURE 5: Potentiodynamic polarization curves of carbon steel in an aqueous solution of $0.25 \mathrm{M} \mathrm{Na}_{2} \mathrm{SO}_{4}$ and $0.3 \mathrm{M} \mathrm{Na}_{2} \mathrm{~S}$ at temperature $25^{\circ} \mathrm{C}$, at different $\mathrm{pH}$.

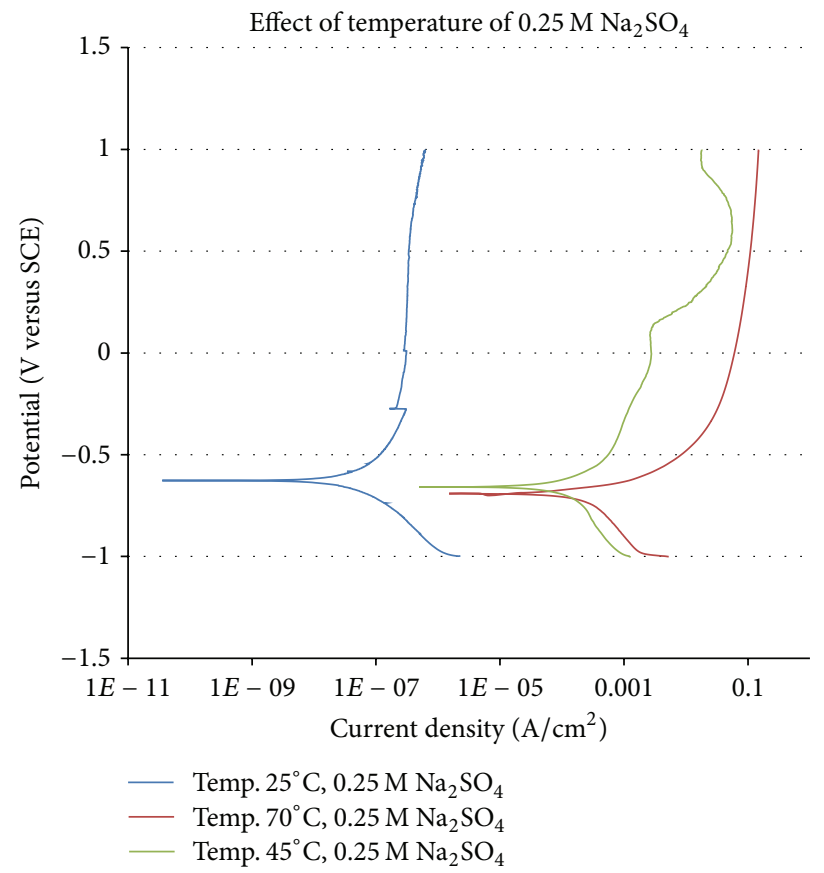

FIgURE 6: Potentiodynamic polarization curves of low carbon steel in $0.25 \mathrm{M} \mathrm{Na}_{2} \mathrm{SO}_{4}$ solution at $(\mathrm{pH}=8)$ at different temperature.

the metallic surface. Temperature also increases the $I_{L}$, the limiting current density of the concentration polarization, and hence shifts the polarization curves to the right.

3.2. Electrochemical Impedance Spectroscopy (EIS). The phenomenon at the interface of the solid metal and aqueous electrolyte is a complex process consisting of a line of positively and negatively charged ions, capacitance due to double layer, corroded product or film formation on surfaces, polarization resistance $\left(R_{p}\right)$, pore resistance $\left(R_{\mathrm{po}}\right)$, and various types of impedance due to diffusion of ions, movement of charge in or away from metal surface, and adsorption of cation and anion. The whole phenomenon can be represented by an equivalent AC electrical circuit. The phenomenon can be interpreted 


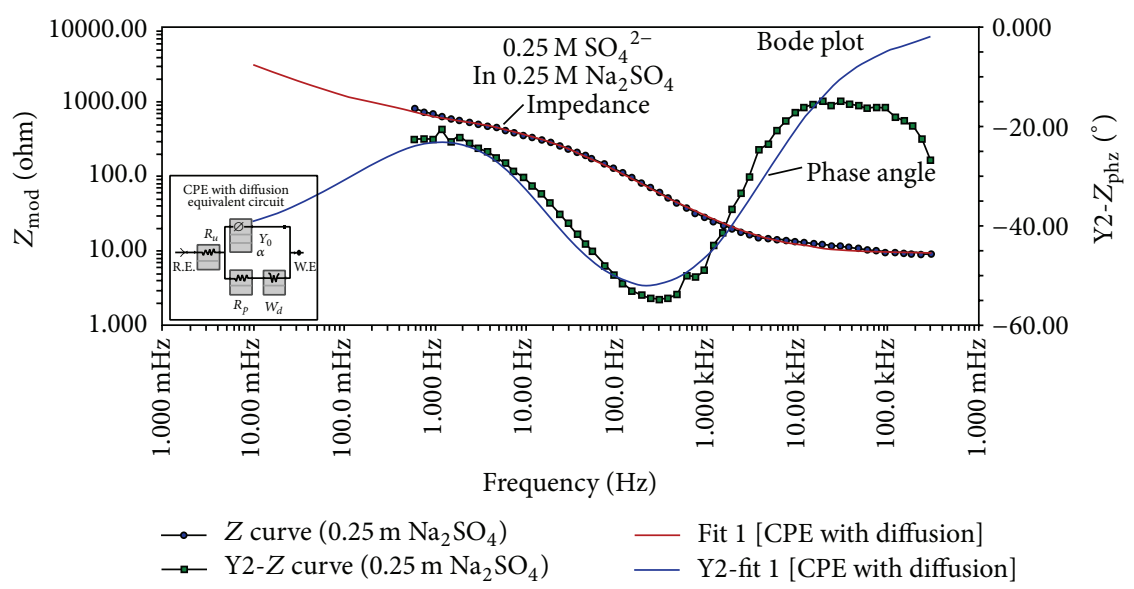

(a)

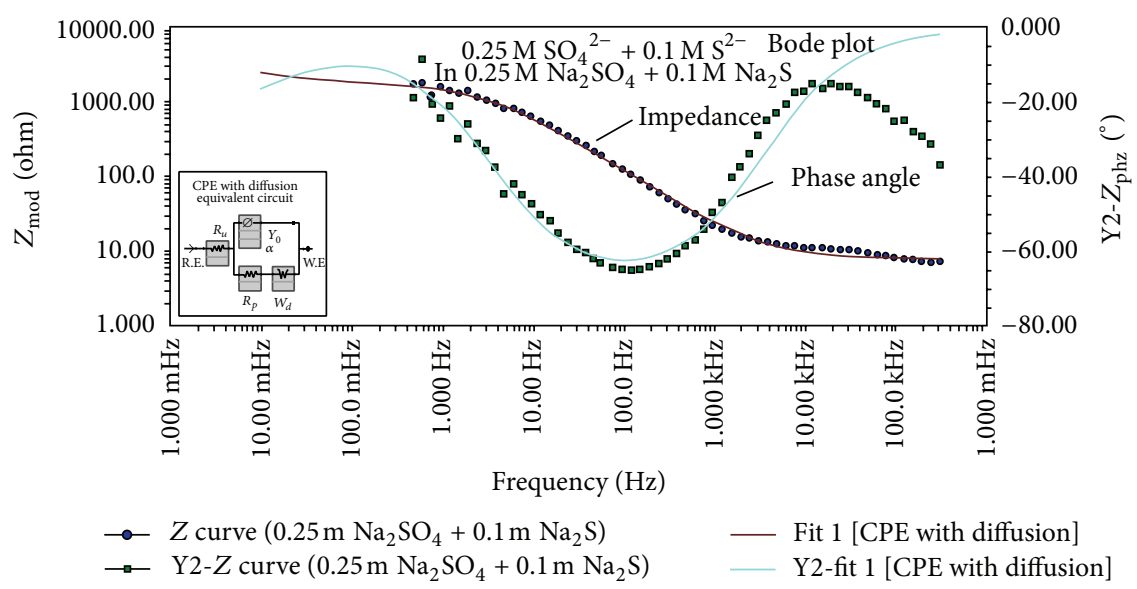

(b)

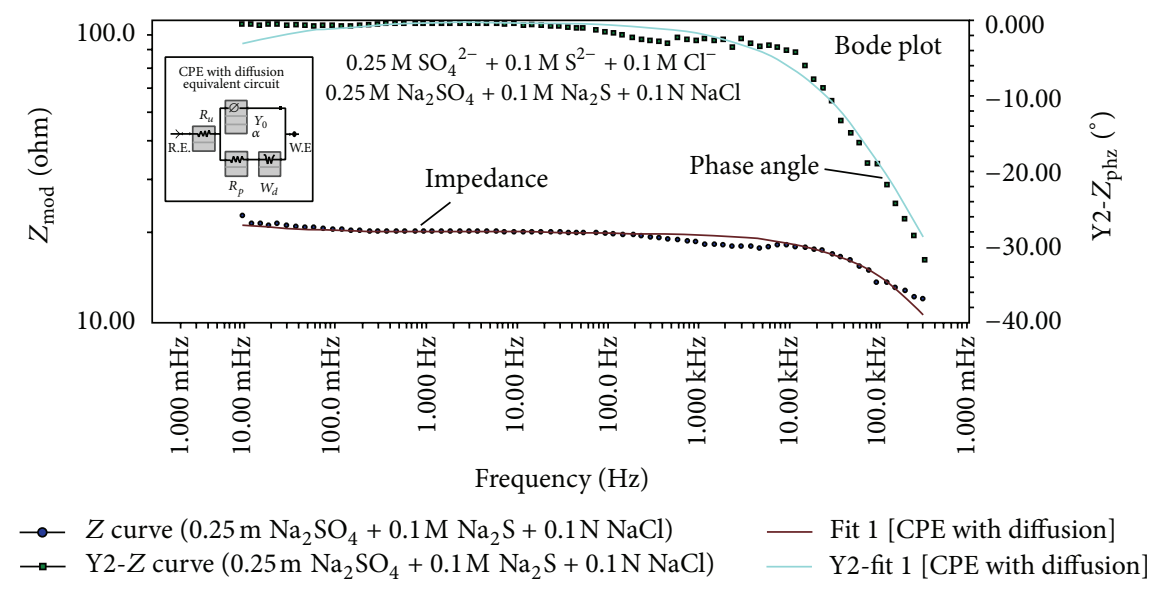

(c)

FIgURE 7: Bode plots of carbon steel in $\mathrm{SO}_{4}{ }^{2-}, \mathrm{SO}_{4}{ }^{2-}+\mathrm{S}^{2-}$, and $\mathrm{SO}_{4}{ }^{2-}+\mathrm{S}^{2-}+\mathrm{Cl}^{-}$solution at $\mathrm{pH} 8$ and temperature $25^{\circ} \mathrm{C}$.

from the Bode plots, which are depicted and discussed in the following section for various corrosive species.

Figure 7 displays the Bode plots of carbon steel in solutions of $\mathrm{SO}_{4}{ }^{2-}, \mathrm{SO}_{4}{ }^{2-}+\mathrm{S}^{2-}$, and $\mathrm{SO}_{4}{ }^{2-}+\mathrm{S}^{2-}+\mathrm{Cl}^{-}$. It is to be noticed that, in all the solutions, EIS data match the model of Randle circuit with a Warburg resistance, $W_{d}$ (given in the inset of each figure), that prevails at the metalsolution interface. It is seen that the impedance decreases with addition of different aggressive ions compared to those with base solution of only $\mathrm{SO}_{4}{ }^{2-}$. This decrease in impedance leads to more current flow across the interface and hence increase in corrosion rate. There is a phase angle shift with 


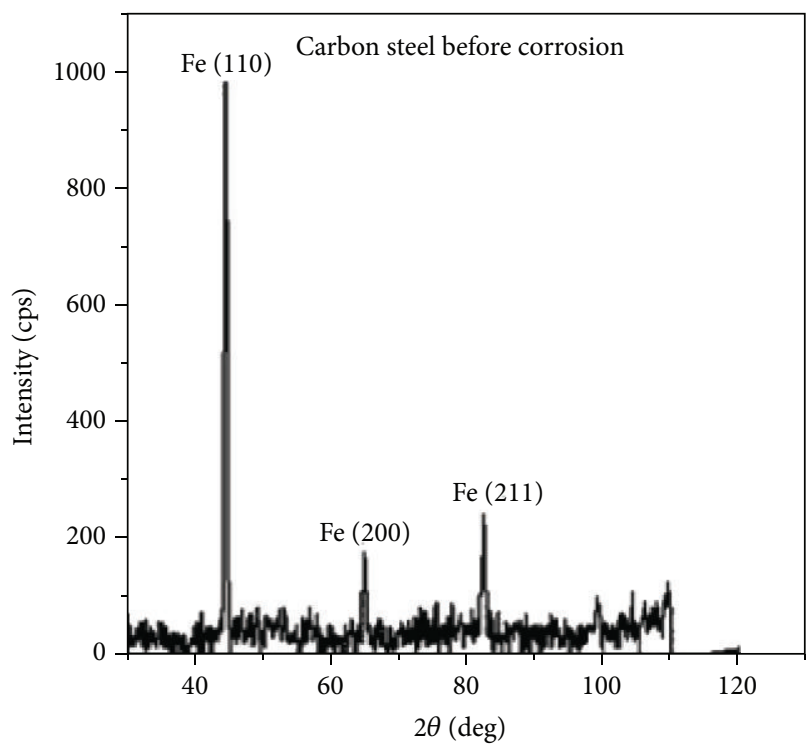

(a)

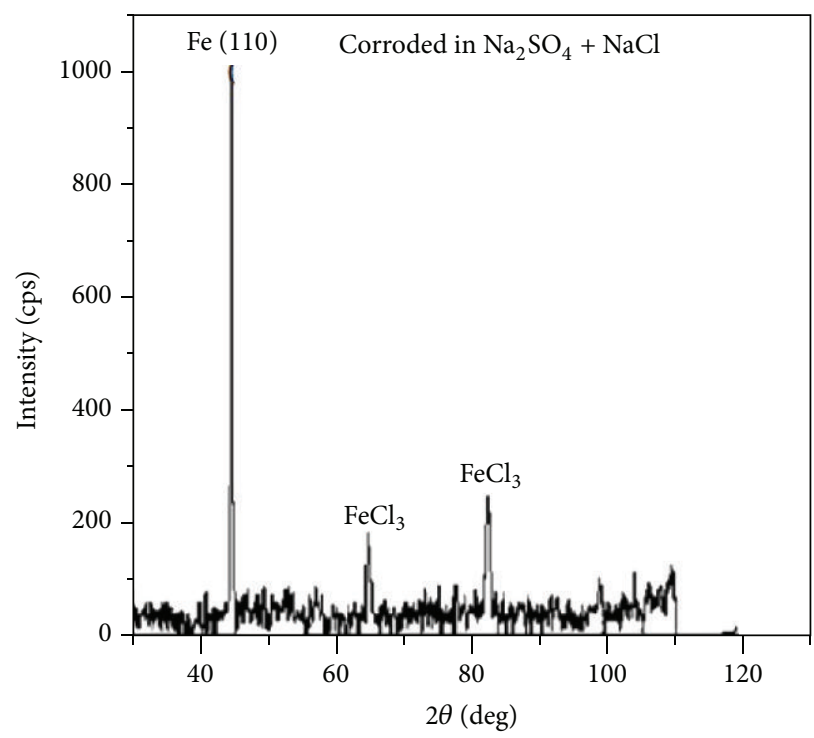

(c)

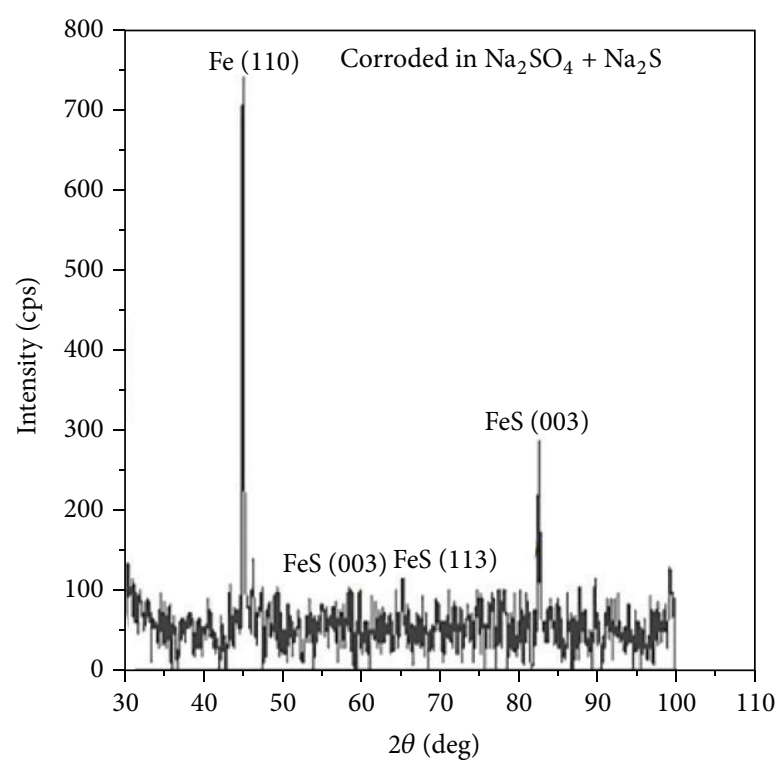

(b)

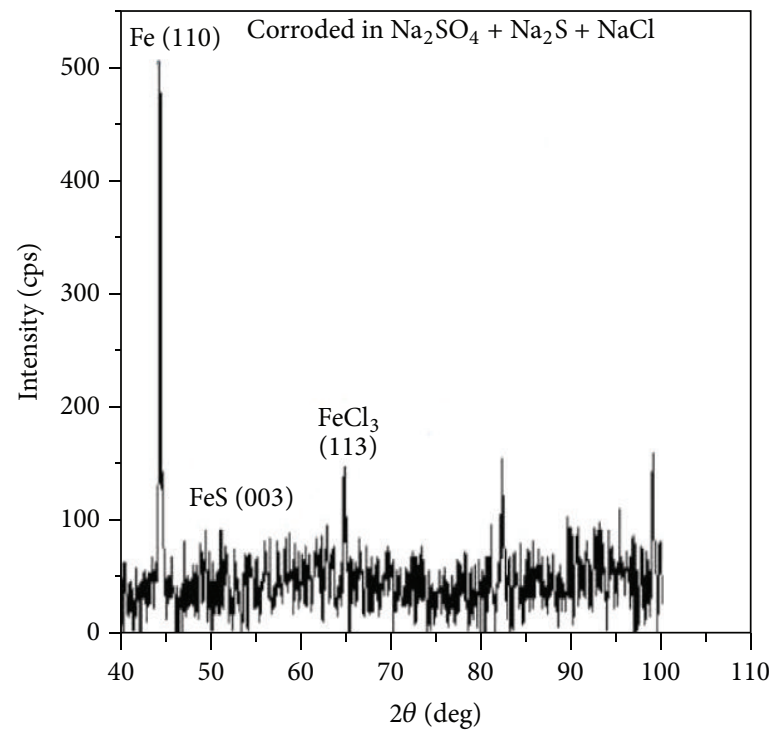

(d)

FIGURE 8: X-ray diffraction showing peaks of different corroded phases.

frequency. The minimum phase angle reaches much less than 90 degrees, indicating the capacitance in the circuit is not a pure capacitance but constant phase element, $\operatorname{CPE}(Y)$, and is given by the capacitive impedance equation $Z=$ $1 / C(j w)^{-\alpha}$, where $\alpha$ is fraction varying from 0 to 1 ; the value less than one indicates that it does not behave ideally as pure capacitance. At high frequency, the value of impedance $Z_{\bmod }$ is roughly equal to $R_{S}$, while at low frequency the value is $\left(R_{S}+R_{P}\right)$. Both can be determined from the blots. Table 1 depicted the computed values of the EIS parameters. It is seen that polarization resistance decreases with addition of more types of ions which support the polarization results of corrosion rates increase as found in Figures 2, 3, and 4. The increase in corrosion rate is supported by the EIS data, increase in $Y_{0}$ which behaves like capacitance, and decrease in polarization resistance (Table 2). The values of $\alpha$ indicate that the capacitance behaves like constant phase element rather than pure capacitance. The Warburg resistance $W_{d}$ which signifies resistance to the flow of ions from the solution to corroded metal surface also decreases with addition of more types of ions. All the facts confirm the enhanced corrosion rates of carbon steel in the oil field sea water with presence of $\mathrm{SO}_{4}{ }^{2-}+\mathrm{S}^{2-}+\mathrm{Cl}^{-}$.

3.3. X-Ray Diffraction. The presence of corrosion products of $\mathrm{FeS}, \mathrm{FeCl}_{2}$, and $\mathrm{FeCl}_{3}$ is clearly indicated by the XRD peak intensities in Figure 8. This supports the corrosion enhancement by $\mathrm{SO}_{4}{ }^{2-}, \mathrm{S}^{2-}$, and $\mathrm{Cl}^{-}$ions as found in polarization and EIS studies. 
TABLE 2: Computed EIS parameters.

\begin{tabular}{lcccccc}
\hline Sample & Corrosive ions & $R_{s}(\mathrm{ohm})$ & $R_{p}(\mathrm{ohm})$ & $Y_{0} \mu \mathrm{F}$ & $\alpha$ & $W_{d}(\mathrm{ohm})$ \\
\hline Carbon steel & $\mathrm{SO}_{4}{ }^{2-}$ & 9.443 & 8500.0 & 75.0 & 0.720 & 10.430 \\
Carbon steel & $\mathrm{SO}_{4}{ }^{2-}+\mathrm{S}^{2-}$ & 8.268 & 3700 & 572.2 & 0.769 & 4.187 \\
Carbon steel & $\mathrm{SO}_{4}{ }^{2-}+\mathrm{S}^{2-}+\mathrm{Cl}^{-}$ & 13.31 & 95 & 905.6 & 0.602 & 2.432 \\
\hline
\end{tabular}
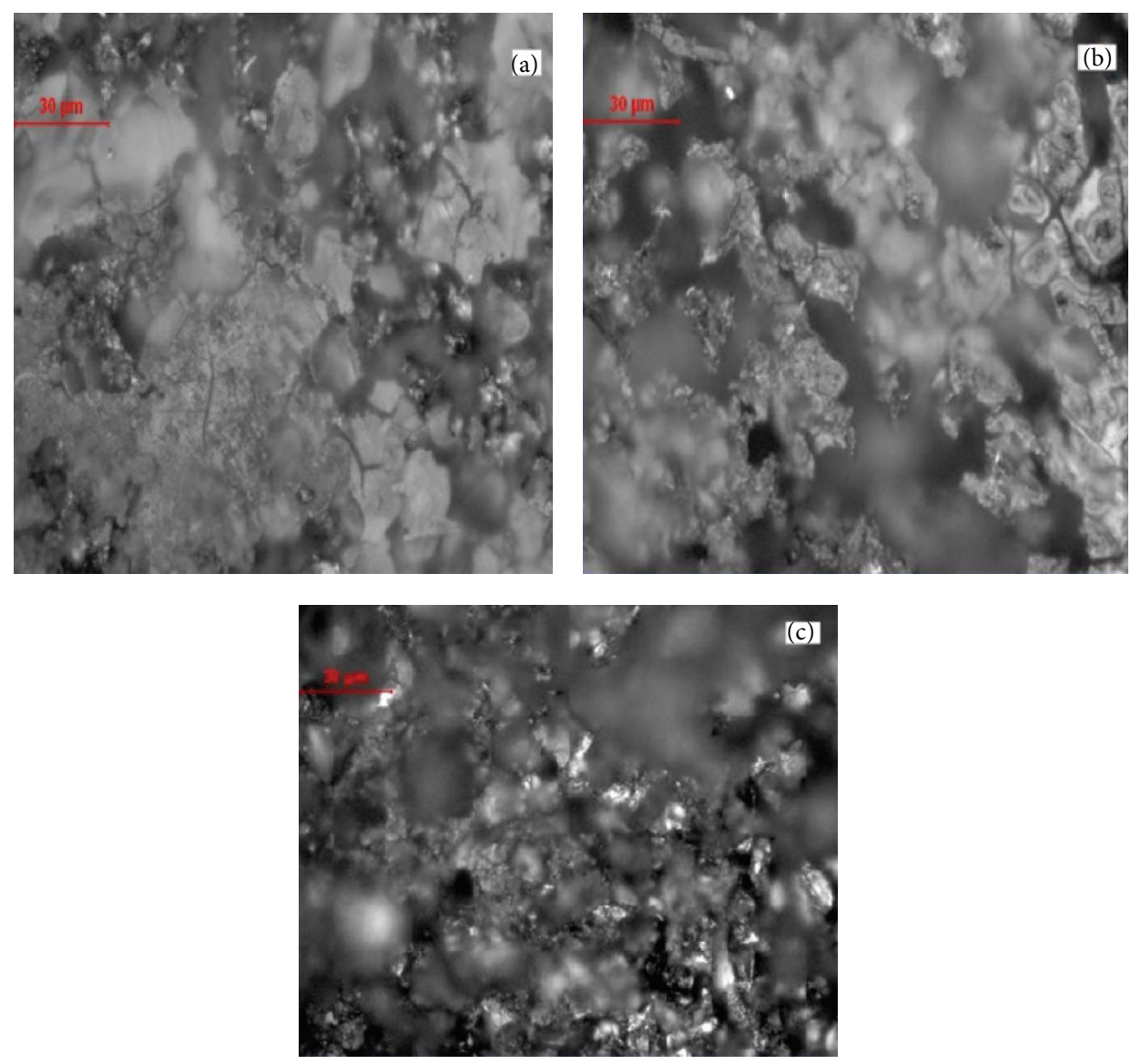

Figure 9: Optical microscopy images of corroded steel. (a) $\mathrm{Na}_{2} \mathrm{SO}_{4}$, (b) $\mathrm{Na}_{2} \mathrm{SO}_{4}+\mathrm{Na}_{2} \mathrm{~S}$, and (c) $\mathrm{Na}_{2} \mathrm{SO}_{4}+\mathrm{Na}_{2} \mathrm{~S}+\mathrm{NaCl}$.

3.4. Optical and SEM Microscopy Images. The microstructures by optical microscopy clearly show (Figure 9) the corroded structure of steel with products of corrosion over it. The form of corrosion seems to be uniform, not localized. SEM images (Figure 10) distinctly reveal how the degree of degradation increases with presence of ions in the solutions from $\mathrm{SO}_{4}{ }^{2-}$ to $\mathrm{SO}_{4}{ }^{2-}+\mathrm{S}^{2-}$ to $\mathrm{SO}_{4}{ }^{2-}+\mathrm{S}^{2-}+\mathrm{Cl}^{-}$. It is interesting to observe from the morphology of SEM image at higher magnification (Figure 11) that the corrosion has taken place at grain boundary as well as grain body but the attack at grain boundary is very prominent with sulphide $(\mathrm{S})$ corrosion crack. The corrosion products of sulphide compounds as well as element sulphur are clearly revealed. The structure of SEM images shows almost catastrophic failure with the presence of minor and major cracks when the seawater is enriched with the presence of all three corrosive ions, $\mathrm{SO}_{4}{ }^{2-}, \mathrm{S}^{2-}$, and $\mathrm{Cl}^{-}$. The morphology of SEM image analysis along with
$\mathrm{XRD}$ is in complete agreement with the corrosion data of the polarization experiments and EIS.

From (5)-(8), it is seen that $\mathrm{SO}_{4}{ }^{2-}$ is cathodically reduced to give rise to $\mathrm{S}^{2-}$. It is observed from the polarization curve (Figure 1) that the increase of $\mathrm{SO}_{4}{ }^{2-}$ concentration depolarizes the cathodic curves much more compared to anodic ones, shifting $E_{\text {corr }}$ towards the negative potential. The release of $\mathrm{S}^{2-}$ from the reaction produces corrosion products: iron sulfides $\left(\mathrm{FeS}_{x}\right)$ on carbon steel surface. They are nonstoichiometric iron sulfide films mainly composed of mackinawite and pyrrhotite Berner [21-26]. The black color of mackinawite phase is also seen as corrosion products in optical microstructures (Figures 9(a) and 9(b)).

The deterioration of metal due to contact with $\mathrm{S}^{2-}\left(\mathrm{H}_{2} \mathrm{~S}\right)$ and moisture is sour corrosion. The forms of sour corrosion are uniform (Figure 9(b)), pitting, and stepwise cracking (Figures 10(c) and 11(b)). 

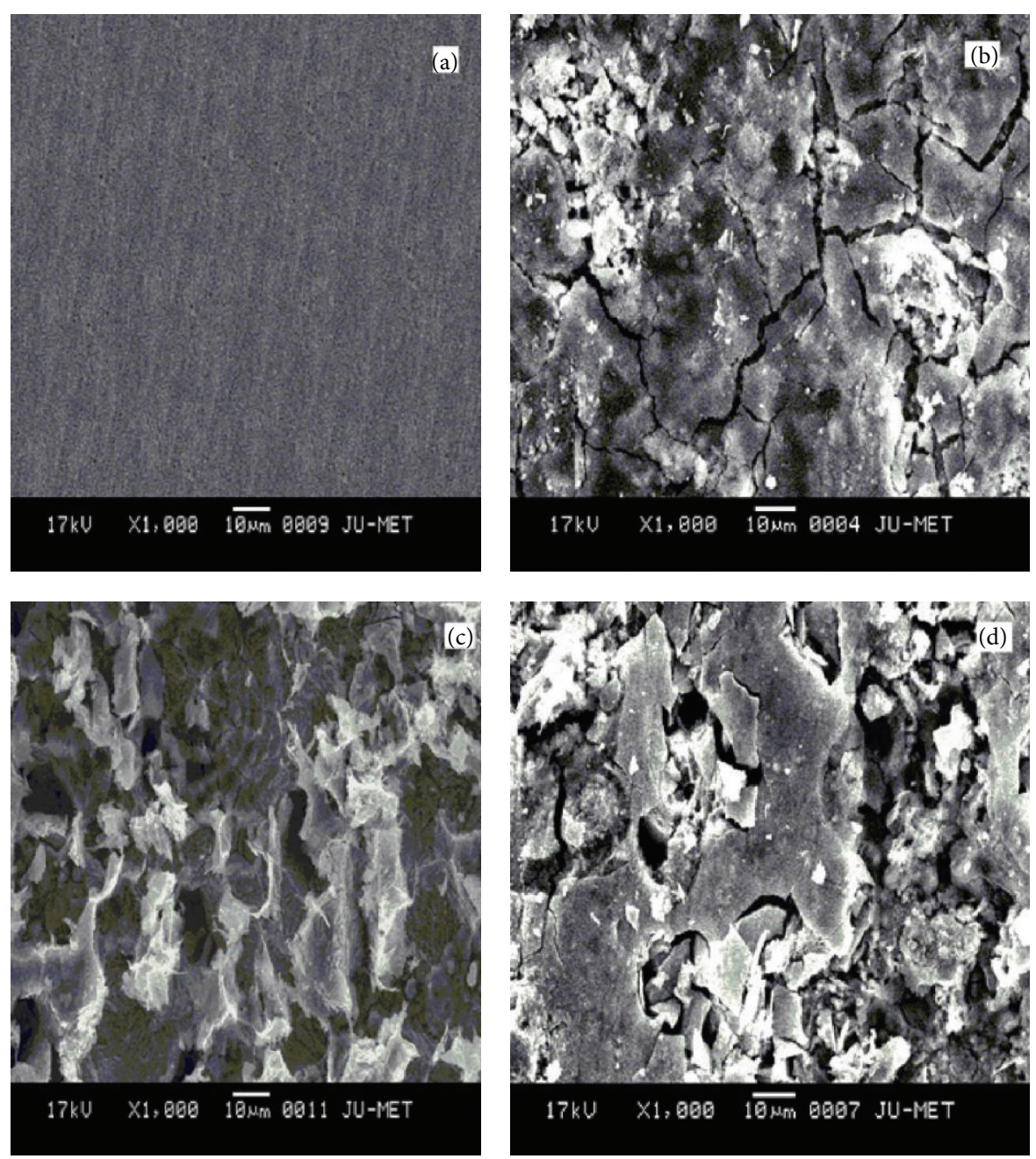

FIGURE 10: SEM images of corroded steel (a) before corrosion, (b) in $\mathrm{Na}_{2} \mathrm{SO}_{4}$, (c) in $\mathrm{Na}_{2} \mathrm{SO}_{4}+\mathrm{Na}_{2} \mathrm{~S}$, and (d) in $\mathrm{Na}_{2} \mathrm{SO}_{4}+\mathrm{Na}_{2} \mathrm{~S}+\mathrm{NaCl}_{\text {. }}$

The general equation of sour corrosion can be expressed as follows [21]:

$$
\mathrm{S}^{2-}+2 \mathrm{H}^{+}=\mathrm{H}_{2} \mathrm{~S}(\mathrm{aq}) \quad E=0.097 \mathrm{~V} \text { versus SCE }
$$

Hydrogen sulphide dissociates to produce proton and bisulphide as described [22] by the following equations:

$$
\begin{gathered}
\mathrm{H}_{2} \mathrm{~S}(\mathrm{aq})=\mathrm{H}^{+}+\mathrm{HS}^{-} \quad K=9.1 \times 10^{-8} \\
\mathrm{HS}^{-}=\mathrm{H}^{+}+\mathrm{S}^{2-} \quad K=9.1 \times 10^{-12}
\end{gathered}
$$

This reaction scheme shows that the presence of hydrogen sulfide can contribute to the concentration of sulfide at the surface by dissociation rather than charge exchange with the surface. The sulfide concentration at the surface is, therefore, dependent on the concentration of aqueous hydrogen sulfide in the electrolyte as well as the reduction processes of sulfate.

$\mathrm{H}_{2} \mathrm{~S}$ exhibits the different role in anodic process of carbon steel depending on the $\mathrm{pH}$ value in the solutions. The local supersaturation of $\mathrm{FeS}_{x}$ could be formed on the carbon steel surface via the following reaction, with the nucleation and growth of one or more of the iron sulfide, mackinawite:

$$
\mathrm{H}_{2} \mathrm{~S}+\mathrm{Fe}+\mathrm{H}_{2} \mathrm{O} \longrightarrow \mathrm{FeS}_{x}+2 \mathrm{H}+\mathrm{H}_{2} \mathrm{O}
$$

The black corrosion products $\left(\mathrm{FeS}_{x}\right)$ formed on the steel surface in the $\mathrm{H}_{2} \mathrm{~S}$-containing solutions could be observed (Figure 9(b)). The addition of chloride to the corrosion system did not exhibit any localized corrosion; rather it drastically increased the $i_{\text {corr }}$ values and shifted $E_{\text {corr }}$ towards the negative potential (Figures 3 and 4), depolarizing the anodic reactions. The increase in $i_{\text {corr }}$ with $\mathrm{Cl}$ addition seems to have modified the anodic substrate area (Figures 9(c) and 10(d)) and has enhanced the exchange current density for the iron oxidation process.

\section{Conclusion}

All three corrosive ions $\mathrm{SO}_{4}{ }^{2-}, \mathrm{S}^{2-}$, and $\mathrm{Cl}^{-}$have a strong effect on increasing the corrosion rate of carbon steel.

Cathodic reduction of $\mathrm{SO}_{4}{ }^{2-}$ generates elemental $\mathrm{S}$ or $\mathrm{S}^{2-}$ ions, in addition to $\mathrm{S}^{2-}$ from $\mathrm{H}_{2} \mathrm{~S}$ in oil. The species 

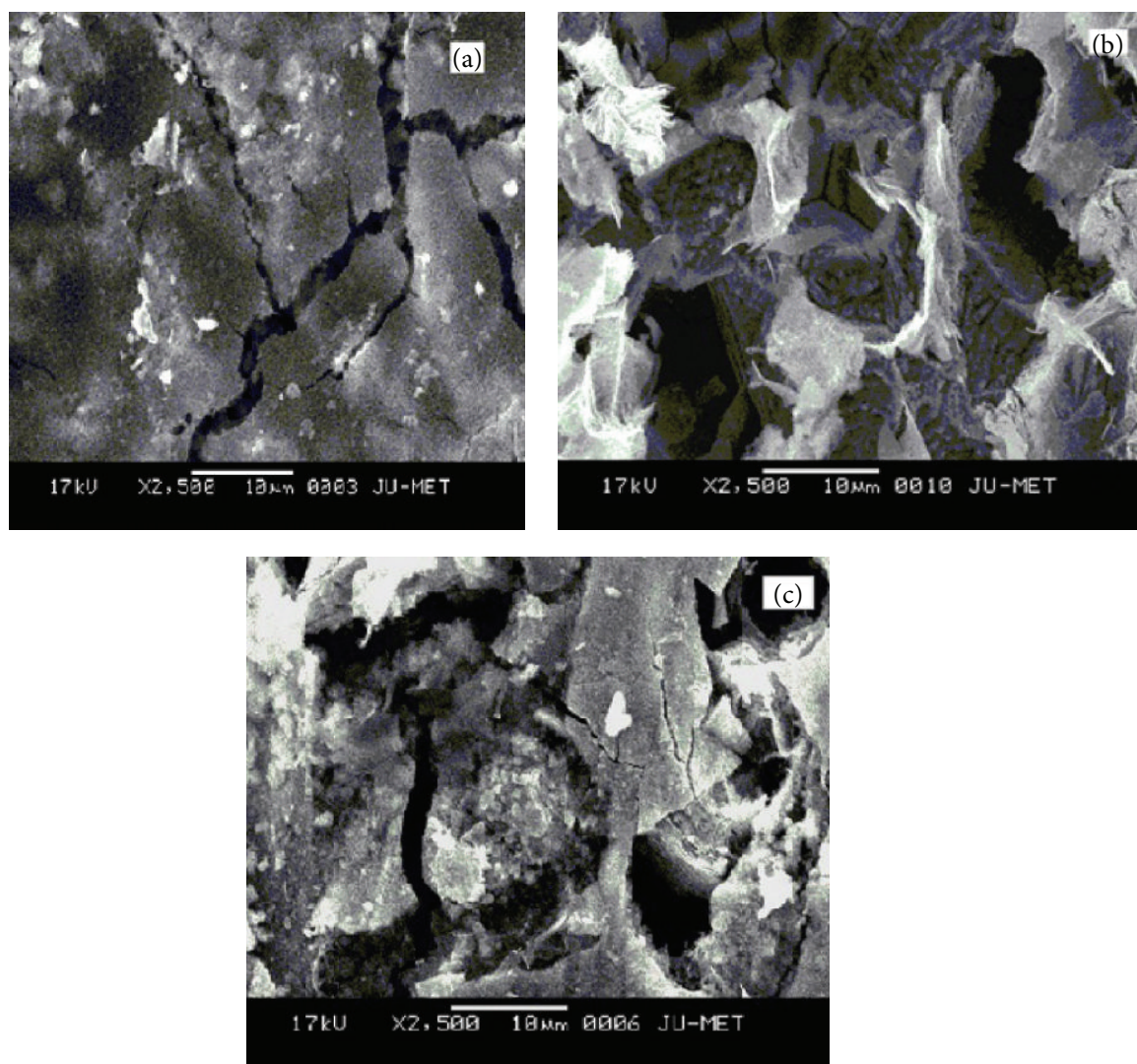

FIGURE 11: SEM images of corroded steel (a) in $\mathrm{Na}_{2} \mathrm{SO}_{4}$, (b) in $\mathrm{Na}_{2} \mathrm{SO}_{4}+\mathrm{Na}_{2} \mathrm{~S}$, and (c) in $\mathrm{Na}_{2} \mathrm{SO}_{4}+\mathrm{Na}_{2} \mathrm{~S}+\mathrm{NaCl}$.

cause major corrosion with formation of $\mathrm{FeS}_{x}$ as corrosion products. The attack is found at grain boundary with sulphide cracking as well as some grain body degradation. The effect of addition of $\mathrm{Cl}^{-}$is the increase of $i_{\text {corr }}$ values by hundreds of times possibly due to enhancement of exchange current density of the anodic reactions.

\section{Conflict of Interests}

The authors declare that there is no conflict of interests regarding the publication of this paper.

\section{Acknowledgments}

The authors would like to acknowledge "COE, TEQUIP" in Jadavpur University for the support of this work.

\section{References}

[1] S. Nešić, "Key issues related to modelling of internal corrosion of oil and gas pipelines-a review," Corrosion Science, vol. 49, no. 12 , pp. 4308-4338, 2007.

[2] L. T. Popoola, A. S. Grema, G. K. Latinwo, B. Gutti, and A. S. Balogun, "Corrosion problems during oil and gas production and its mitigation," International Journal of Industrial Chemistry, vol. 4, aticle 35, 2013.

[3] B. W. A. Sherar, P. G. Keech, and D. W. Shoesmith, "The effect of sulfide on the aerobic corrosion of carbon steel in near-neutral
pH saline solutions," Corrosion Science, vol. 66, pp. 256-262, 2013.

[4] B. W. A. Sherar, I. M. Power, P. G. Keech, S. Mitlin, G. Southam, and D. W. Shoesmith, "Characterizing the effect of carbon steel exposure in sulfide containing solutions to microbially induced corrosion," Corrosion Science, vol. 53, no. 3, pp. 955-960, 2011.

[5] F. M. Song, "A comprehensive model for predicting $\mathrm{CO}_{2}$ corrosion rate in oil and gas production and transportation systems," Electrochimica Acta, vol. 55, no. 3, pp. 689-700, 2010.

[6] M. Hairil Mohd and J. K. Paik, "Investigation of the corrosion progress characteristics of offshore subsea oil well tubes," Corrosion Science, vol. 67, pp. 130-141, 2013.

[7] J. Tang, Y. Shao, T. Zhang, G. Meng, and F. Wang, "Corrosion behaviour of carbon steel in different concentrations of $\mathrm{HCl}$ solutions containing $\mathrm{H}_{2} \mathrm{~S}$ at 90 ○C," Corrosion Science, vol. 53, no. 5, pp. 1715-1723, 2011.

[8] Z. A. D. Foroulis, "Role of solution $\mathrm{pH}$ on wet $\mathrm{H}_{2} \mathrm{~S}$ cracking in hydrocarbon production," Corrosion Prevention and Control, vol. 40, no. 4, pp. 84-89, 1993.

[9] M. A. Veloz and I. González, "Electrochemical study of carbon steel corrosion in buffered acetic acid solutions with chlorides and $\mathrm{H}_{2}$ S," Electrochimica Acta, vol. 48, no. 2, pp. 135-144, 2002.

[10] S. Arzola and J. Genescá, "The effect of $\mathrm{H}_{2} \mathrm{~S}$ concentration on the corrosion behavior of API 5L X-70 steel," Journal of Solid State Electrochemistry, vol. 9, no. 4, pp. 197-200, 2005.

[11] H. Y. Ma, X. L. Cheng, S. H. Chen et al., “Theoretical interpretation on impedance spectra for anodic iron dissolution in acidic solutions containing hydrogen sulfide," Corrosion, vol. 54, no. 8, pp. 634-640, 1998. 
[12] H. Ma, X. Cheng, S. Chen, C. Wang, J. Zhang, and H. Yang, "An ac impedance study of the anodic dissolution of iron in sulfuric acid solutions containing hydrogen sulfide," Journal of Electroanalytical Chemistry, vol. 451, no. 1-2, pp. 11-17, 1998.

[13] H. Ma, X. Cheng, G. Li et al., "The influence of hydrogen sulfide on corrosion of iron under different conditions," Corrosion Science, vol. 42, no. 10, pp. 1669-1683, 2000.

[14] H.-H. Huang, W.-T. Tsai, and J.-T. Lee, "Electrochemical behavior of the simulated heat-affected zone of A516 carbon steel in $\mathrm{H}_{2} \mathrm{~S}$ solution," Electrochimica Acta, vol. 41, no. 7-8, pp. 1191-1199, 1996.

[15] J. Tang, Y. Shao, J. Guo, T. Zhang, G. Meng, and F. Wang, “The effect of $\mathrm{H}_{2} \mathrm{~S}$ concentration on the corrosion behavior of carbon steel at 90 ॰C," Corrosion Science, vol. 52, no. 6, pp. 2050-2058, 2010.

[16] P. Smith, S. Roy, D. Swailes, S. Maxwell, D. Page, and J. Lawson, "A model for the corrosion of steel subjected to synthetic produced water containing sulfate, chloride and hydrogen sulfide," Chemical Engineering Science, vol. 66, no. 23, pp. 57755790, 2011.

[17] R. E. Melchers, "Development of new applied models for steel corrosion in marine applications including shipping," Ships and Offshore Structures, vol. 3, no. 2, pp. 135-144, 2008.

[18] M. H. Mohd, D. K. Kim, D. W. Kim, and J. K. Paik, "A timevariant corrosion wastage model for subsea gas pipelines," Ships and Offshore Structures, vol. 9, no. 2, pp. 161-176, 2014.

[19] R. E. Melchers and J. K. Paik, "Effect of flexure on rusting of ship's steel plating," Ships and Offshore Structures, vol. 5, no. 1, pp. 25-31, 2010.

[20] M. Shehadeh and I. Hassan, "Study of sacrificial cathodic protection on marine structures in sea and fresh water in relation to flow conditions," Ships and Offshore Structures, vol. 8, no. 1, pp. 102-110, 2013.

[21] R. A. Berner, "Thermodynamic stability of sedimentary iron sulfides," The American Journal of Science, vol. 265, pp. 773-785, 1967.

[22] R. H. Hausler, L. A. Goeller, R. P. Zimmerman, and R. H. Rosenwald, "Contribution to the "filming amine" theory: an interpretation of experimental results," Corrosion, vol. 28, no. 1, pp. 7-16, 1972.

[23] P. Taylor, "The stereochemistry of iron sulfides-a structural ration for the crysta llization of some metastable phases from aqueous solution," American Mineralogist, vol. 65, pp. 10261030, 1980.

[24] R. A. Berner, "Iron sulfides formed from aqueous solution at low temperatures and atmospheric pressure," The Journal of Geology, vol. 72, pp. 293-306, 1964.

[25] D. T. Rickard, "The chemistry of iron sulphide formation at low temperatures," Stockholm Contributions in Geology, vol. 20, pp. 67-95, 1969.

[26] A. J. Bard, R. Parsons, and J. Jordan, Standard Potentials in Aqueous Solution, CRC Press, 1st edition, 1985. 

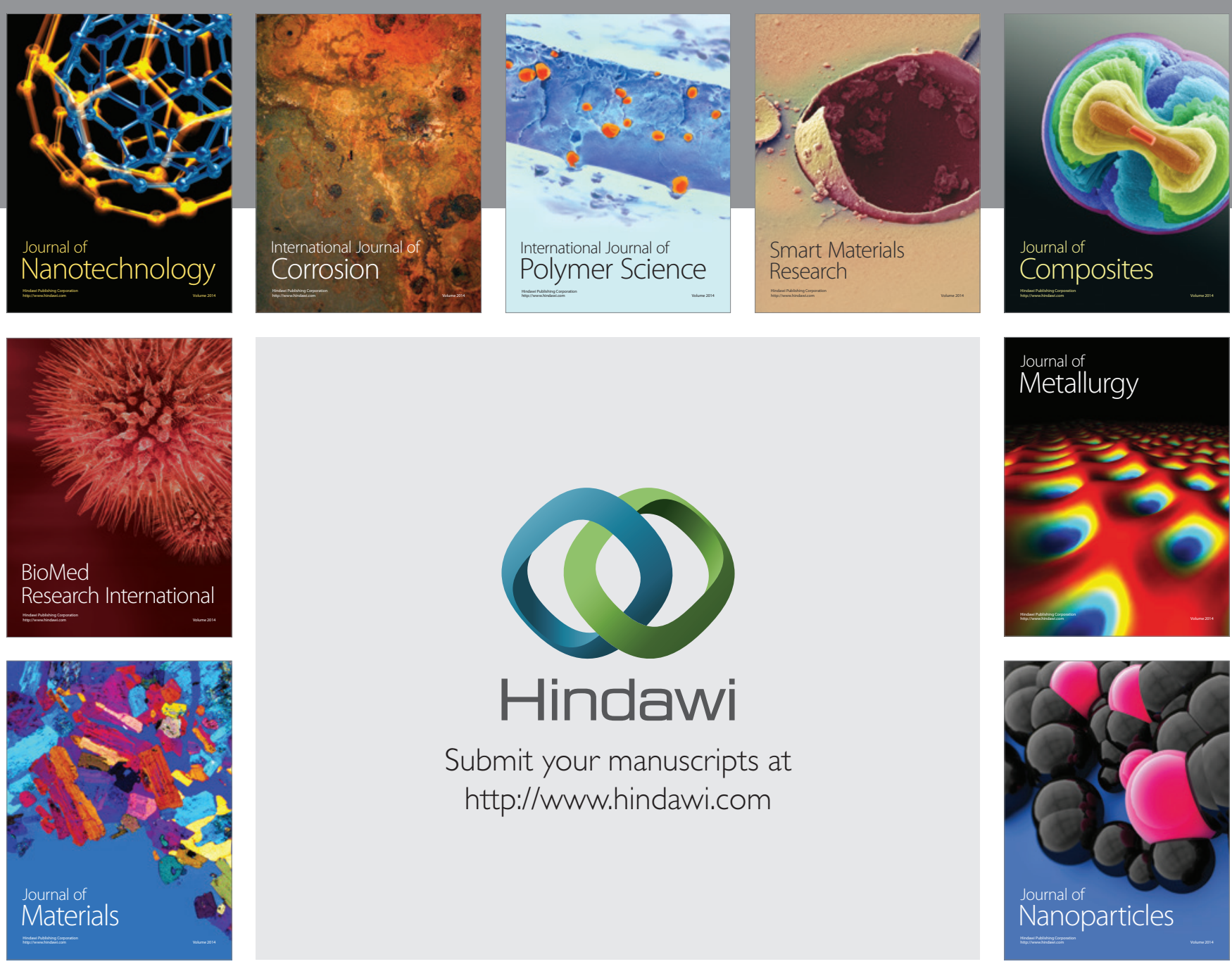

Submit your manuscripts at http://www.hindawi.com
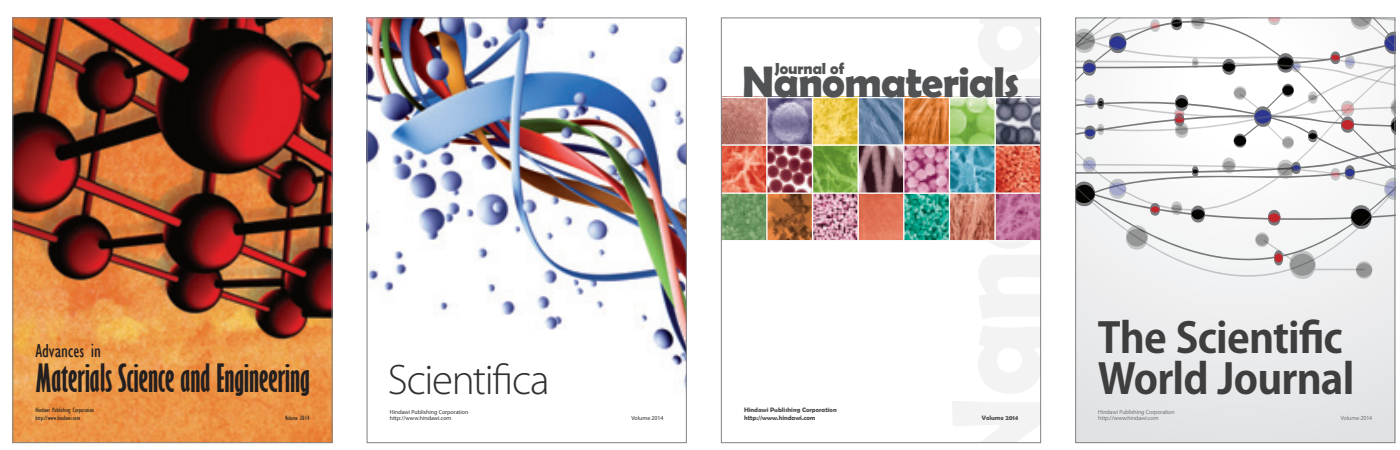

\section{The Scientific World Journal}
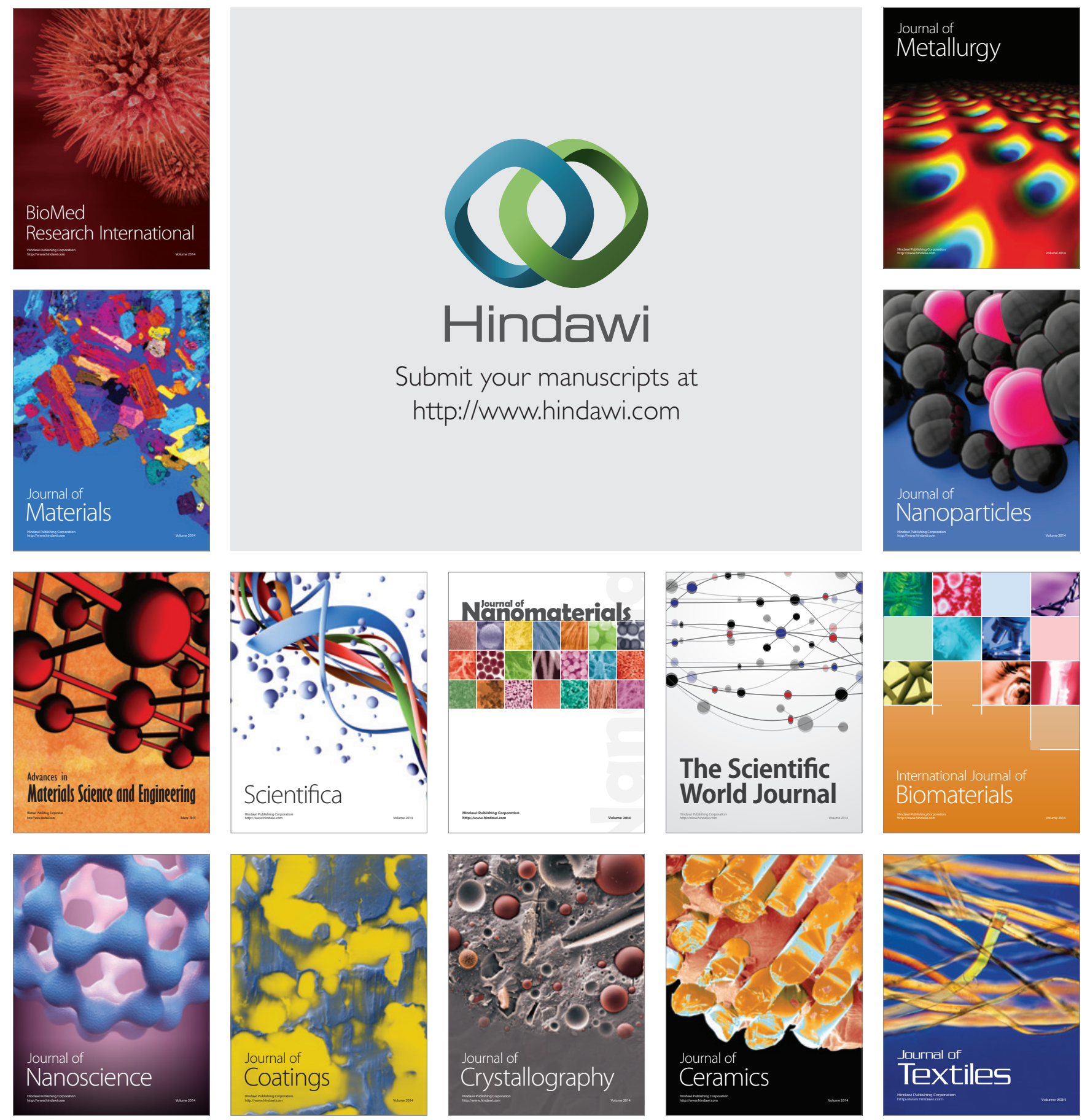